\title{
How Do Budget Level and Type of Incentives Influence Performance?
}

\author{
Caesar Marga Putri ${ }^{1}$ \\ Indah Wirantika Susanti ${ }^{2}$ \\ ${ }^{1.2}$ Faculty of Economic and Business, University of Muhammadiyah Yogyakarta, Indonesia \\ email: caesar.margaputri@umy.ac.id
}

DOI: https://doi.org/10.24843/JIAB.2019.v14.i01.p04

\section{Jurnal Ilmiah Akuntansi dan Bisnis (JIAB)}

https://ojs.unud.ac.id/index.php/jiab/ user/profile

Volume 14

Nomor 1

Januari 2019

Halaman 34-40

p-ISSN $\underline{2302-514 X}$

e-ISSN $\underline{2303-1018}$

\section{INFORMASI ARTIKEL}

Tanggal masuk:

08 November 2018

Tanggal revisi:

21 Desember 2018

Tanggal diterima:

02 Januari 2019

\section{ABSTRACT}

This research experimentally compares the influence of budget-based contracts and social incentives on individual performance. This paper compares two different types of budget-based contracts, budget-linear and budget-fixed, along with social incentives on individual performance. Assigning individuals in different budget levels, $75 \%$ or $100 \%$, to perform complex tasks will lead to different performance outputs. The results show that individual performance will be higher when they receive a budget-linear contract. Social incentives have a strong impact on both types of budget-based contracts. The result of the study on the influence of budget levels confirms previous research that higher budget levels will led to higher performance when compared with lower budget levels.

Keywords: Budget-based incentive contracts, social incentives, budget level, task complexity, individual performance.

\section{Bagaimana Budget Level dan Tipe Insentif Mempengaruhi Kinerja?}

\begin{abstract}
ABSTRAK
Penelitian ini membandingkan secara empiris pengaruh budget-based contract dan insentif sosial pada kinerja individu. Penelitian ini menguji dua tipe budgetbased contract; budget-linier contract dan budget-fixed contract, dengan insentif sosial pada kinerja individu. Individu akan menerima tugas yang bersifat komplek dengan target anggaran yang berbeda $75 \%$ atau $100 \%$ tergantung randomisasi yang mereka terima. Perlakuan ini diharapkan akan menghasilkan kinerja yang berbeda. Hasilnya menunjukkan bahwa kinerja individu akan lebih tinggi ketika mereka menerima budget-linier contract dari pada apabila mereka menerima budget-fixed contract. Sedangkan insentif sosial memberikan pengaruh yang kuat dibandingkan dua tipe insentif yang lain. Hasil pengujian target anggaran juga mengkonfirmasi penelitian sebelumnya yang menyatakan bahwa target anggaran yg lebih tinggi akan meningkatkan kinerja individu.

Kata kunci: Budget-based incentive, insentif sosial, target anggaran, kompleksitas tugas, kinerja individu.
\end{abstract}

\section{INTRODUCTION}

Agency theory is focused on the model of optimal incentive contract to solve moral hazard problem as a risk neutral-pinciple that may do by agent (Bruggen and Moers, 2007). Agency model lets principle select evaluation system for performance that specifis performance measures to set the base of agent's compensation and the function which link performance measure to that compensation (Lambert, 2007). However, agency problem still exist due to some reasons such as the failure in establishing interesting model that is easy to manage and control. In addition, problem may come from the agent's monetary utility is defined 
only over the compensation received based on the compensation contract (Lambert, 2007). The role of incentive to individual performance has been investigated by previous researches (Kelly et al., 2015; Al-Nsour, 2012; Anthony and Govindarajan, 2007; Bouwens and Lent, 2006; Bonner and Sprinkle, 2002; Bailey et al., 1998).

Incentive became the most powerful factor that been predicted could influence performance (Hossain, 2014; Guymon et al., 2008; Burggen and Moers, 2007; Fargher et al., 1998). Some researchers have distinguished incentive into two type, financial and non-financial (Hosain, 2014). Spreitzer (2006) states that individual behavior can be influenced by two dominant factors, economic gain and social factor. Both factors can create incentive for employee (Hossain, 2014). Non-material incentive can be social acceptance such as recognition. Haidar et al., (2015) state that non-financial reward not only increase individual performance but also employee satisfaction in organization. Tippet and Kluvers (2009) also state employees are motivated by non-economic reward. Fisher et al., (2003); Fisher et al., (2003) investigate deeply about financial reward by dividing budget-based contract into budget-linier contract and budget-fixed contract. The result shows that individual performance is influenced more by budgetlinier contract than by budget-fixed contract.

The budget-based contract is based on individual achievement against target. Goal-setting theory assumes that there is desire on individual to have goals, choose goals and be motivated by these goals (Locke and Lathman, 2002). Goal effects performance and many factors that mediate goalperformance relation. Performance is a positive function of goal difficulty until individuals reach the ability limits. Robbins and Judge (2015) explain that specific goal is an evidence to increase performance. They explain that higher level of goal difficulty which is not easy to be done and finally could be done will have a better result than lower level of budget difficulty because higher level of budget difficulty will increase the effort of individuals to achieve that goal (Robbins and Judge, 2015).

Arnold and Artz (2015) state that budget provides tool for activities planning accurately and realistically by setting the budget level into easy and difficult level for motivating manager. Further, Fisher et al., (2003) state that individual performance will higher when budget in the medium level than when it is on the high level or lower level. While Oktavia (2014) states that individual performance will higher when budget in the lower level than on the higher level when they do less complex task while in complex task the result is opposite. The achieving of target both on higher or lower level of target also influenced by task complexity. Task complexity influences individual performance (Bailey and Fessler, 2011; Bonner, 2002). They found that task complexity will increases individual effort, however, performance will remain the same. Bailey dan Fessler, (2011)state that financial incentive will motivate individual more to achieve performance in less complex task. Kartini et al., (2016) also prove that budget-linier contract is more effective on less complex task than in more complex task. However, in the real condition the nature of task is complex task.

Based on Bailey and Fessler (2011) prove financial incentive is effective in motivating individual on less complex task, however, they have not investigated the effectiveness of non-financial incentive through complex task. Kartini et al., (2016) also prove that budget-linier contract is more effective to increase individual performance than budget-fixed contract. However, the comparison of the effectiveness of incentive type, financial and nonfinancial, on Individual performance has not been investigate deeply in the previous researches. Inconsistency of previous result shows that lower target more encourage individual to perform better, however, other results state that goal difficulty has positive effect on performance until individuals reach their ability limit. Nowadays, in modern work environment, social incentives is more important than other type of incentives. The increasing number of social media also encourage the increasing of social incentive such us recognition. So this research extend the previous researches about budget-based incentive contract by comparing the influence of social incentive with budget-linear contract and budgetfixed contract on individual performance. This compensation affect is not stand alone, it also influenced by the goal or budget level to be achieved by the individual (fisher et al, 2003). Locke and Latham (1990) explain that monetary incentive affects on performance will higher when there is specific target. Finally, this research also trying to investigate the effect of budget level or budget target on performance. 
The agency theory addresses on optimal incentive contract for agent-principle relationship to achieve goal congruence. Based on economic theory individual will maximizing their effort to achieve target when there are incentive provided. Budgetbased incentive contract effects individual's performance than other type of incentive contract such as fixed-pay, piece-rate and flat-rate (Hannan, 2005; Hirs, 1992; Fisher et al., 2003). Budget-based incentive contract is divided into budget-linear contract and Budget-fixed contract. Under budgetlinier contract, compensation will not be paid if the target does not achieved (under target) and fixed bonus will be paid if target achieved. If the performance is above the target compensate ion will paid per unit uses piece-rate scheme. In other hand, under budget-fixed contract, if performance is above target, there is no additional compensation paid. It means that individual only receive fixed bonus. Fisher et al (2003) shows that group performance higher if they receive compensation that calculated using budget-linier contract than budget-fixed contract and piece-rate scheme. Guymon et al., (2008) shows that group performance will higher under budget-based contract than a piece-rate contract. Individual who under budget-linear contract will allocate more effort to achieve the target because they will receive more additional incentive if the performance above the target. In other hand, individual who under group of budget-fixed contract will not receive additional incentive. As a result, first hypothesis as follows:

$\mathrm{H}_{1}$ : Individual performance will be higher when individual receives budget-linear contract than budget-fixed contract.

The social identity theory explain about psychological process that comes up when person identifies herself/himself as a member of group. This theory lead to how individual will behave. Noneconomic factors are relevant in decision making and control (Sprinkle, 2003; Awasthi and Pratt, 1990). Fehr and Gachter (1999); Towry (2003) state that social incentive plays an important role in modern work environment. When manager notice how important employee participation in decision making towards organization improvement (Hosain, 2014), incentive scheme option from principal to effect the agent effort become important issue. Fehr and Schmidt, (2004) state Social incentive and ethical issue as important variable that can effect individual behavior in multi-tasking job. Bruggendan Moers, (2007) using experimental approach proved that social incentive as part of non-financial-incentive able to effect multi-task assignment. Haider et al, (2015) state that non-financial can effect employee satisfaction in organization level. The recognition from others is more important nowadays, as the increasing of social media, individual feel more satisfied when they get recognition than other type of incentive. Consequently, the second hypothesis as follows,

$\mathrm{H}_{2}$ : Individual performance will be higher when individual receives social incentive than budgetbased contract.

Goal-setting theory describes how goal setting influence subsequent performance because effort will be allocated more to reach the budget level. Robbins and Judge (2015) state that specific goal will lead to higher performance. Oktavia et al (2014) also prove that the increasing of budget target will lead to the increasing of individual performance. Loce and Lathman (1990) show that specific target influences the effectiveness of monetary incentive towards individual performance. However, Bonner and Sprikle (2002) and Fatseas and Hirst (1992) state that individual performance will increase if the target is achievable. However, Fisher et al., (2003) state that the highest level of performance is reached when budget level on moderate difficulty than on lower or higher level. In sum, the increasing of budget level will increase time-work allocation and effort to achieve it. As a result, the increasing of effort will increase performance. This lead to the third hypothesis:

$\mathrm{H}_{3}$ : Individual performance will increase when budget level increases.

\section{RESEARCH METHOD}

Using accounting student as participant, this research uses true experiment method $2 \times 3$ between subjects. True experiment is an experiment method that completely control extraneous variables by randomization (Nahartyo and Utami, 2016). Using undergraduate student is intended to get high validity of the relationship between dependent and independent variables. Undergraduate student is free from extraneous variables such as fairness and working experiences. 
Table 1. Experimental Design (2x3)

\begin{tabular}{lllll}
\hline & & & Incentive & \\
\hline \multirow{3}{*}{ Complex Task } & & $\begin{array}{l}\text { Budget-linier } \\
\text { contract }\end{array}$ & $\begin{array}{l}\text { Budget - Fixed } \\
\text { contract }\end{array}$ & Social Incentive \\
\cline { 3 - 5 } & $75 \%$ & Group 1 & Group 2 & Group 3 \\
& $100 \%$ & Group 4 & Group 5 & Group 6 \\
\hline
\end{tabular}

Dependent variable of this research is individual performance. Using instrument adopted from Libby (2001), performance is measured by calculating correct translation from symbol to alphabet and numbers done by the respondent since this is a complex task. Good performance will be measured if the participant can achieve the target. BudgetBased Incentive Contracts as independent variable manipulated using instrument developed by Fisher et al (2003) and adopted by Kartinid et al., (2016) and this is contract is divided into budget-linear contract dan budget-fixed contract. This contract will not pay compensation for individual performance bellow the target and a fixed bonus will be paid once the target is achieved.

The contract equation Kartini et al., (2016) is:

$\mathrm{TP}=(\mathrm{a} \times \mathrm{A})+\mathrm{B}(\mathrm{s}-\mathrm{t})$, if $\mathrm{s}>\mathrm{t}$

Where:

TP : Total pay for employee

a : 1 if individual output is equal to or greater than the budget target; 0 otherwise

A : Fixed bonus amount

Rp 7.500 for $75 \%$ budget level

Rp 10.500 for 100 budget level

B : Bonus with piece rate method Rp 500 per question

s : Correct answer

$\mathrm{t}$ : Number of correct answer targeted

Budget-fixed contract, this contract is nonlinear, no compensation will be paid for individual performance bellow or above the target and fixed bonus will be paid when the budget is achieve.

The contract equation Kartini et al., (2016) is:

$\mathrm{TC}: \mathrm{a} \times \mathrm{A}$

Where:

TC : Total compensation

a : 1 if individual output is equal to or greater than the budget target; 0 otherwise

A : Fixed bonus amount

Rp 7.500 for $75 \%$ budget level

\section{Rp 10.500 for 100 budget level}

Social incentive refers to social acceptance such as recognition, status, enjoyment work environment etc. (Hossain, 2014). Social Incentive, in this experiment used to measure non-financial reward adopted from Bruggen and Moers (2007) which refers to recognition of individuals due to their achievement. Budget level refer to the level at which they should be set, medium to achieve $(75 \%)$ or difficult to achieve (100\%). This instrument adopted from Fisher et al (2003) who divided into easy, medium and difficult. If participants got $75 \%$ budgetlevel, they have to finish minimum 15 question correctly. In other hand, they have to finish 20 question correctly if the target is $100 \%$. While, Complex task refers to complex task-specific strategies for proper completion (Bonner et al., 2002). In complex task, symbols are translated into alphabet using translation key (Libby, 2001). This instrument adopted from Oktavia et al., (2016) who refer to Libby, 2001. Presence of complex task in this experiment by asking the participants to translate from symbol to both alphabet and number.

The procedure of the experiment begins with assigning participant to group randomly into six groups by giving an envelope with different decoding. The envelope contain different treatment depend on group. First of all, participant doing a-minutes training session to make themselves familiar with the task. Second step is work session, in group 3 and 6, participants are asked to introduce their selves in order to increase cohesion among participant and to ease social identity among participants to exit condition for social incentive and test by asking each participant to find the other participants name. After all, examiner of the experiment told that the result of the experiment (number of correct) answer will be published on the announcement board near the department of accounting office that ranked from the highest to the lowest score. It will enable everyone to read participant's name who get highest or lowest score. 
Meanwhile, in group 1, 2, 4, and 5 participant will be informed about target that they have to achieve and the type of incentive that they will get depend on the target in each group. Third step, participants performed an experiment task by translating symbol into letter of alphabet and number. The last is manipulation check by answering some question. This series of experiment is ended by fill on demographic data. After thirty minutes, the number of correct answer of each participant has been calculated and experimenter distribute the payment to the participants based on the type of incentive stated before.

\section{RESULT AND DISCUSSION}

There are seventy five students participated in this experiment, but only seventy students passed the manipulation check and fulfill the requirement for statistical test. Hypothesis will be test using two way ANOVA. Hypothesis 1 will be accepted if the total mean of group 1 and group 4 is higher than total mean of group 2 and group 5. Hypothesis 2 will be accepted if total mean of group 1 and group 2 lower than group 3 or total mean of group 4 and 5 lower than total mean of group 6 . Hypothesis 3 will be accepted if total mean of group 4, group 5 and group 6 is higher than total mean of group 1 , group 2 and group 3.

Table 2. Result of Statistic test

\begin{tabular}{|c|c|c|c|c|}
\hline \multirow[t]{2}{*}{ Means $\bar{X}$} & \multicolumn{4}{|l|}{ (S.D) } \\
\hline & & & Incentive & \\
\hline & & $\begin{array}{l}\text { Budget - linier } \\
\text { contrac }\end{array}$ & $\begin{array}{l}\text { Budget - fixed } \\
\text { contract }\end{array}$ & Social incentive \\
\hline & $75 \%$ & Group 1 & Group 2 & Group 3 \\
\hline & & $\begin{array}{l}\bar{X}=14,33 \\
(1,16)\end{array}$ & $\begin{array}{l}\bar{X}=13,83 \\
(1.37)\end{array}$ & $\begin{array}{l}\bar{X}=16,50 \\
(0.99)\end{array}$ \\
\hline Complex Task & $100 \%$ & $\begin{array}{l}\text { Group 4 } \\
X=16,58 \\
(1,37)\end{array}$ & $\begin{array}{l}\text { Group 5 } \\
X=14,33 \\
(0,9)\end{array}$ & $\begin{array}{l}\text { Group } 6 \\
X=19,41 \\
(6,63)\end{array}$ \\
\hline
\end{tabular}

Table 3 shows that direct and interaction effect of incentive and target is significant. Mean total of group 1 and group 4 is 15.46 is greater than mean total group 2 and group 5,14.21, it means hypothesis 1 that predicts individual performance will be higher when individual receives budget linier contract than budget-fixed contract is accepted. Mean total of group 3 and group 6 is 17.86 is greater that group 1 and group 4 or group 2 and group 5, It means hypothesis 2 that predicts individual performance will be higher when individual receives social incentive than budget-based contract is accepted. Mean total group 4.5, 6 is 14.89 which is greater than mean total of group 1, 2 and 3,16.7, it means hypothesis 3 which predicts individual performance will be higher when individual work under budget level than medium budget level is accepted.

Budget-linier contract increases individual performance than budget-fixed contract (Octavia, 2014; Hannan, 2005; Fisher, 2003). It prove that individual performance will increase if they receive linier incentive than if only fixed incentive. The influence of social incentive, recognition in this context, will influence higher performance than if they receive financial incentive. It is confirm previous research Hossain (2014). It prove that in modern era, non-financial incentive such as recognition will play importance role because person feel their

Table 3. Tests of Between-Subjects Effects Result

\begin{tabular}{|c|c|c|c|c|}
\hline \multirow[b]{2}{*}{ Source } & \multicolumn{4}{|c|}{ Dependent Variable: Individual performance } \\
\hline & $\begin{array}{r}\text { Ind } \\
\text { Tyne JI Sum of Sauares }\end{array}$ & $d f$ & F & $\mathrm{Sig}$ \\
\hline Incentive & 177.19 & 2 & 38.58 & 0,000 \\
\hline Target & 59.86 & 1 & 26.07 & 0,000 \\
\hline Incentive*Target & 18.28 & 2 & 3.98 & 0,024 \\
\hline
\end{tabular}


existence is recognized. Higher budget level influence higher individual performance because individual will allocate more effort to achieve target. It is consistent with previous research that specific goal or high target will lead to high performance (Oktavia, 2016, Robbins and Judge, 2015).

\section{CONCLUSION}

The influence of incentive on individual performance is approved, although, type of incentive give different effect on the performance. Performance of individual increases when social incentive is received than others. Meanwhile, individual performance will higher when individual receive budget-linear incentive than budget-fixed incentive. Overall, this current result is useful for managers, researchers and others related parties. Manager could use this finding to decide type of incentive to be adopted in order to increase individual performance in the organization.

There are some limitations of this research, since it is experimental method, the internal validity is high but the degree of generalization is low. Therefore next research should be use other method to find more generalized of result. This research also paper based, next research could be conducted using web based. Last, future research should investigate other factors that may influence not only on individual performance but also on group performance. Comparing the effectiveness of factors on influencing performance of individual and group.

\section{REFERENCES}

Al-Nsour, M. 2012. Relationship between Incentives and Organizational Performance forEmployees in the Jordanian Universities. International Journal of Business and Management. 7(1), 78-89.

Anthony, Robert N., dan Govindarajan, Vijay. (2003). Sistem Pengendalian Manajemen, Jakarta: Salemba Empat.

Bailey, C. D., and Fessler, N. J. (2011). The moderating effects of task complexity and task attractiveness on the impact of monetary incentives in repeated task. Journal of Management Accounting Research. 23, 189-210.

Bonner, S.E.,and Sprinkle, G. B. (2002). The Effect of Monetary Incentives on Effort and Task Performance: Theories, Evidence, and A Framework for Research. Accounting, Organization and Society. 27, 303-345.
Bouwens, Jan and Lent, L., V (2006). Performance Measurement Properties and The Effect of Incentive Contract. Journal of Management Accounting Research. 28, 55-75.

Burggen, A and Moers, F (2007). The Role of Financial Incentives and Social Incentives in Multi-Task Setting. Journal of Management Accounting Research. 19: 25-50.

Fatseas, Victor A., and Hirst, Mark K. (1992). Incentives Effect of Assigned Goals and Compensations Schemes on Budgetary Performance. Accounting and Business Research. 22 (88), 347-355.

Fargher, L. N, Rankin, FW and Sayre, T, L (1998). The Effects of Promotion Incentives on Delegated Investment Decisions: A Note. Journal of Management and Accounting Research.

Fehr, E., and K. M. Schmidt. (2004). Fairness and incentives in a multi-task principal-agent model. Scandinavian Journal of Economics 106, 453474.

Fehr, E., and S. Ga"chter. 1999. Collective action as a social exchange. Journal of Economic Behavior and Organization 39, 341-369.

Fisher, Joseph G., Peffer, Sean A., and Sprinkle, Geoffrey B. (2003). Budget-Based Contracts, Budget Levels, and Group Performance. Journal of Management Accounting Research. 15, 51-74.

Guymon, R.N, Balakhrishan, R, Tubbs, R, M (2008). The Effect of Task Interdependence and Type of Incentive Contract on Group Performance. Journal of management accounting research. 20, (1-18)

Haider, Maqsood. Aamir, Alamzeb. Hamid, AbuBakar A., and Hashim, Muhammad (2015). A Literatue Analysys on the Importance of NonFinancial Rewards for Employees' Job Satisfaction. Journal of Abasyn Journal of Social Sciences. 8(2).

Hannan, R.L. (2005). The Combined effects of wages and firm profit on employee effort, The Accounting Review. 80, 167-188.

Hossain. (2014). The Influence of Financial and NonFinancial Rewards; and Employee Empowerment on Task Motivation and Firm Performance ofBangladesh Front Line Employees: A Critical Approach. European Journal of Business and Management 6 (7). 
Kartini, A, Herwiyanti. E., dan Mafudi. (2016). Pengaruh Budget-Based Incentive Contract, Target Kinerja, dan KompleksitasTugas terhadap Kinerja Individu. Simposium Nasional Akuntansi XIX, Lampung.

Kelly, K. O, Webb, R. A and Vance, T (2015) The Interactive Effect of Ex Post Goal Adjustment and Goal Difficulty on Performance. Journal of Management Accounting Research. 27 (1), $1-25$.

Lambert., R.A(2007) Agency Theory and Management Accounting. Hand book of Management Accounting Research. (1), 247-267.

Libby, Theresas. (2001). Referent Cognition and Budgetary Fairness: A Research Note. Journal of Management Accounting Research. 13: 91-105.

Locke, E. A., and Latham, G. P. (1990). A Theory of Goal Setting and Task Performance. Englewood Cliffs, NJ: Prentice-Hall.

Nahartyo, E dan Utami, I, (2016). Panduan Riset Eksperimen. PT. Indek Jakarta.
Oktavia, Rossieta, H., dan Lindawati, G. (2014). Dampak Insentif Moneter Terhadap Kinerja Individu: Peran Dari Kompleksitas Tugas Dan Target Kinerja. 14 (1), 25-44.

Robbins, S. P., dan Timothy A. Judge. (2015). Perilaku Organisasi. Jakarta: Salemba Empat. Spreitzer, G. (2006) Psychological empowerment in the workplace: Dimensions, measurement and validation. Academy of Management Journal. Vol 38(5) pp-1442-1465.

Sprinkle, G. B. 2003. Perspectives on experimental research in managerial accounting. Accounting. Organizations and Society 28: 287-318.

Tippet, J., and Kluvers, R. (2009). Employee Rewards and Motivation in Non Profit Organizations: Case Study from Australia. International. Journal of Business and Management, 4(3), 7.

Towry, K. L. (2003). Control in a teamwork environment-The impact of social ties on the Effectiveness of mutual monitoring contracts. The Accounting Review 4, 1069-1095. 